\title{
Industrial Relations Foresight 2025: The European Union Member States and the Seven Other Major Economies*
}

\author{
Timo Kauppinen \\ University of Helsinki, Helsinki, Finland
}

\begin{abstract}
The topic of this article is industrial relations foresight 2025. Especially research is concentrated on unionisation of today and trends for tomorrow. Participating countries are all European Union 27 Member States and seven major global competitors like Australia, Brazil, China, India, Japan, South Africa, and USA. The future of industrial relations is analysed by using statistical analysis and foresight survey method. National experts from employer and employee unions as well from the state and researcher group gave their replies concerning future development of unionisation in their own country and general values. Statistical analysis tells that unionisation varies from less than $10 \%$ in France to $80 \%$ in the Nordic Countries. Since 1980s, there has been a general trend towards lowering unionisation. According to the foresight analysis that lowering unionisation trend seem to continue for employee trade unions as well as for employer organizations. This is connected to general value change towards individualisation and flexible work practices. These global trends will lead to weakening unionisation, weakening collective bargaining and will challenge the whole system of industrial relations for change.
\end{abstract}

Keywords: foresight, industrial relations, individualisation, flexibility, trade unions, employer organisations, unionisation

\section{Introduction: Unionisation in Selected Countries 1915-2005}

In Europe there has been a general trend of growing trade unionisation of employees since 1930 up to 1980s. France is a clear exception to this general trend with its low and decreasing unionisation since 1950s. Another clear trend from the figure is a general downward trend of unionisation since 1980s. This trend is very strong and united. In the U.S. this downward trend started in the 1950s and in Japan in 1970s.

We can also notice that unionisation varies among countries. Those countries which have high unionisation of today seem to have had higher unionisation also in the earlier years. The same concerns also low unionisation countries. There are some exceptions from this rule like Finland where unionisation was the lowest in the 1930 but the second highest in the 1980s (see Figure 1).

The turning point of the 1980s is closely related to the years of collapse of socialism and strengthening of liberalist market economy. Collective values changed towards individual values, industrial society towards service economy strengthened by new digital technology. Stake holder values were replaced by share holder values and bonuses were connected to wages and salaries. Deregulation, flexibility, and flexicurity were the

\footnotetext{
*Acknowledgment: This author thanks for Christian Welz's help, who is the research managers running this project. Timo Kauppinen, Dr., Adjunct Professor, Industrial Relations, University of Helsinki.

Correspondence concerning this article should be addressed to Timo Kauppinen, Mantypaadentie 9 A 4, 00830 Helsinki, Finland. E-mail: timo.kauppinen43@gmail.com.
} 
leading politics of employers. In the middle of these changes, trade unions lost some of their traditional powers to negotiate collectively wages, working times, and working conditions.

\section{Unionization in different countries}

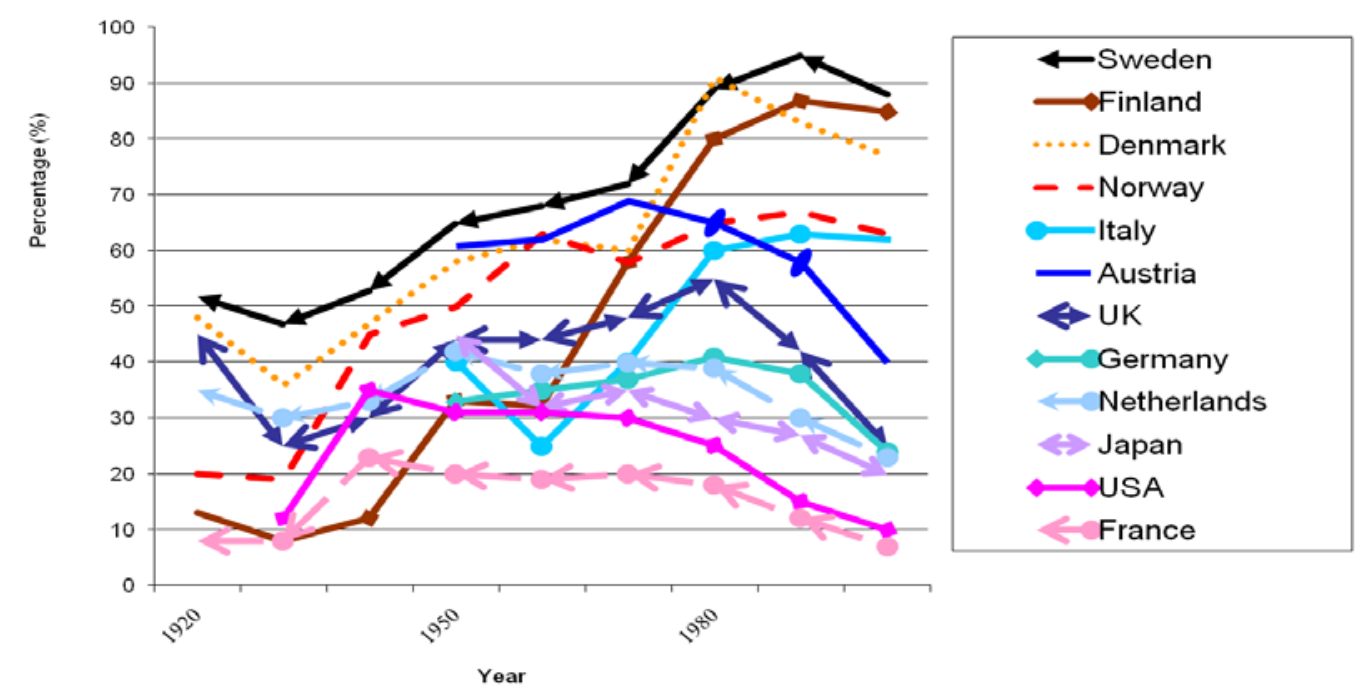

Figure 1. Trade union density rates in selected countries 1915-2005.

Clear cyclical change of trade unionisation will wake up a question of the next possible turning points and possible upward trends of unionisation. When will it happen? Or are we moving permanently to a period of low trade unionisation? And what will happen to the whole system of industrial relations? Will the globalisation mark any change?

\section{Foresight Questions}

Lowering trend of trade union density rates will also put us to think about organisation density of employers. Will it become stronger, weaker or remain the same? How collective agreements are negotiated? Is national, sectoral or company level dominant or is the negotiation process a mixture of all these levels? What will happen to the coverage of collective agreements? Are less or more people covered by collective agreements? What will happen in the national level? Are trend similar in the old 15 and new 12 European Union Member States? Is there any diverging or converging trend towards Europeanisation of industrial relations? And what are the main trends of industrial relations in the global seven countries (Australia, Brazil, China, India, Japan, South Africa, and the U.S.) compared with the EU countries? Is there any trend towards globalisation of industrial relations?

These were the main questions when the European Foundation for the Improvement of Living and Working Conditions, Eurofound, agreed with the researchers Kaia Philips, Raul Eamets, and Epp Kallaste to make a comparative foresight study on industrial relations. Outputs of the project were 34 country reports and a comparative report on industrial relations foresight 2025 including industrial relations environment, actors, processes, outcomes, and impacts. This was a continuation for the previous many projects on actual situation of industrial relations in the EU Member States compared with global seven countries (look references). Timo Kauppinen and Christian Welz have acted as research managers in these projects.

These foresight projects as well as many other projects are related to the European Union challenge to 
modernise European industrial relations in order to make Union globally competitive. Previous foundation reports on the topic have concentrated to analyse the actual situation of industrial relations/social dialogue by producing country reports, comparative summaries and by benchmarking EU industrial relations against the global development.

Foresight approach is very welcome to the Eurofound, which is a tripartite research agency of the European Union. Social partners together with the government representatives make the final decisions on the content of the Eurofound's living and working conditions research work. This ongoing foresight project was targeted to initiate debater on future of industrial relations in the national, EU as well as global level.

\section{Pre-study: Group Work Foresight 2025 on Industrial Relations}

Thinking, debating, and shaping are the essential features of foresight studies. ${ }^{1}$ This was in mind when a "group work foresight" 2020 on industrial relations was carried out in a Eurofound's four-partite seminar in 2006. Participants were representing trade unions, employer organisations, governments, and researchers from 18 European Union countries. National four-partite groups made joint foresights 2020 on the main features of industrial relations in their own countries. Results summarized are:

- Union density rates are expected in declining in the great majority of the old EU 15 Member States but rising in the new EU 10 Member States (joined EU 2004);

- Employer organisation density rate are expected in declining in the great majority of the old EU Member States but rising in the new EU Member States;

- Level of collective bargaining is expected in decreasing and more issues are agreed at the company level in the old EU Member States. Many of the new EU Member States are expected to move from employment contract to company level collective bargaining and even to sectoral collective bargaining;

- Coverage of collective bargaining is expected in declining in the old EU Member States and rising in the new EU Member States;

- Workplace representation is expected to strengthen a bit but views are very diverse in different countries.

A quick hypothesis from the results is that in the European Union there seems to be two contradictory trends: one towards weakening and one towards strengthening of industrial relations. In the old EU Member States social partners are losing members and negotiations are decentralising at the same time when in the new EU Member States social partners are attracting more members and collective bargaining is strengthening.

Methodologically speaking the strength of the group analysis was that foresights were outcomes of joint debate and joint view of four-partite groups. The weakness was that analysis covered only 18 countries from 27 EU Member States and did not allow put Europeanisation into global benchmarking. To combat these shortcomings this new project developed an "expert antenna foresight", which uses online survey for gathering experts' views on the future development of industrial relations.

\section{“Expert Antenna Foresight” Survey 2025}

"Expert antenna foresight" 2025 uses online survey for gathering expert views on future development of industrial relations. Survey covered all EU 27 and Global seven countries from October-December, 2007 to January, 2008. An internet survey allows gather information with very low costs in a short time period.

\footnotetext{
${ }^{1}$ Thinking, debating and shaping the future: Foresight for Europe. Final report prepared by a High Level Group for the European
} Union. EU 2002. 
National "expert" respondents were the representatives of trade union organisations, employer organizations, and governments and also academic experts on industrial relations. Experts were selected from the Eurofound's seminar participation files. Eurofound's national centres assisted in taking contacts if needed. The minimum target was to get at least two responses from each group of representatives in EU 27 countries and at least three responses from academic experts from Global seven countries. The questionnaire ${ }^{2}$ consisted from 16 questions. Answering was made easy by giving only three alternatives: increase, decrease, and remain the same. In the following figures we can read majority's foresight in percents but "weak signals" may be hidden behind the figures. In total 346 fulfilled questionnaires were received from 34 countries.

\section{Foresight on Global Values 2025}

In the winter 2007 survey respondents had very united views on the future trends of societal values. Big majority had a joint view that liberalism in economic policy will increase as well as individualism in everybody's life. Working life flexibility will increase and more and more people are working as self-employed and in atypical employment relations. Job security is also weakening and inequality in incomes is widening by 2025. It is worth to notice that there are no big differences between employees', employers', governments', and academic respondents' views. The same general unity in views concerns also the following reported results on unionisation, collective bargaining, and coverage of collective agreements.

\section{Foresight on Trade Union Density Rates 2025}

In 2004 the trade union density differs significantly between countries ranging from 80\%-70\% in the Nordic Countries to about 10\% in the U.S. and France and only 3\%-6\% in India (Philips \& Eamets, 2007; Van Gyes et al., 2007).

Foresight analysis tells that the same big variability is expected to be in trade union density rates also in 2025. Highest trade union density rates—over 60\%—will be in Denmark, Finland, and Sweden and the lowest rates - 10\% or less — will be in France, U.S., and India (see Figure 2).

In majority of the countries respondents expect some decrease in trade union density rates by 2025. In more than half of the observed countries, the expected changes by 2025 are around -5 to +5 percentage points.

- In the majority of EU 15 countries trade union density rates will decline. The most remarkable decrease is expected in Sweden and Denmark and some increase in Germany, France, and Spain;

- In the majority of EU 12 countries trade union density rates will decrease by 2025. The most dramatic decrease is expected in Malta and Cyprus, while the highest increase in Lithuania and Latvia;

- In Global seven countries majority of respondents expect some decline in the trade union density rates by 2025. In China, Japan, U.S., and Australia decrease would be around three to five percentage points, while in Indian some increase;

- On average, in public sector unionisation is much higher than in the private sector. However, the decline of trade union membership in public sector is not expected to be as dramatic as in the private sector.

There is a tendency that in the countries, where currently the trade union density rate is higher, the decline is expected to be deeper. Increase in density rates is expected in majority of EU 12 countries, while more

\footnotetext{
2 The questionnaire and the survey was designed and administered in the freeware survey program LimeSurvey (Retrieved from http://www.limesurvey.org/). Additionally, respondents could print the questionnaire out from the web link, fill it in on paper and send it afterwards by fax. Also it was possible to use doc-version of the questionnaire, which could have been sent to them by country experts or by survey organisers.
} 
visible declining tendency is expected in EU 15 countries. It shows that some convergence and unification in trade union density rates is taking place in Europe.
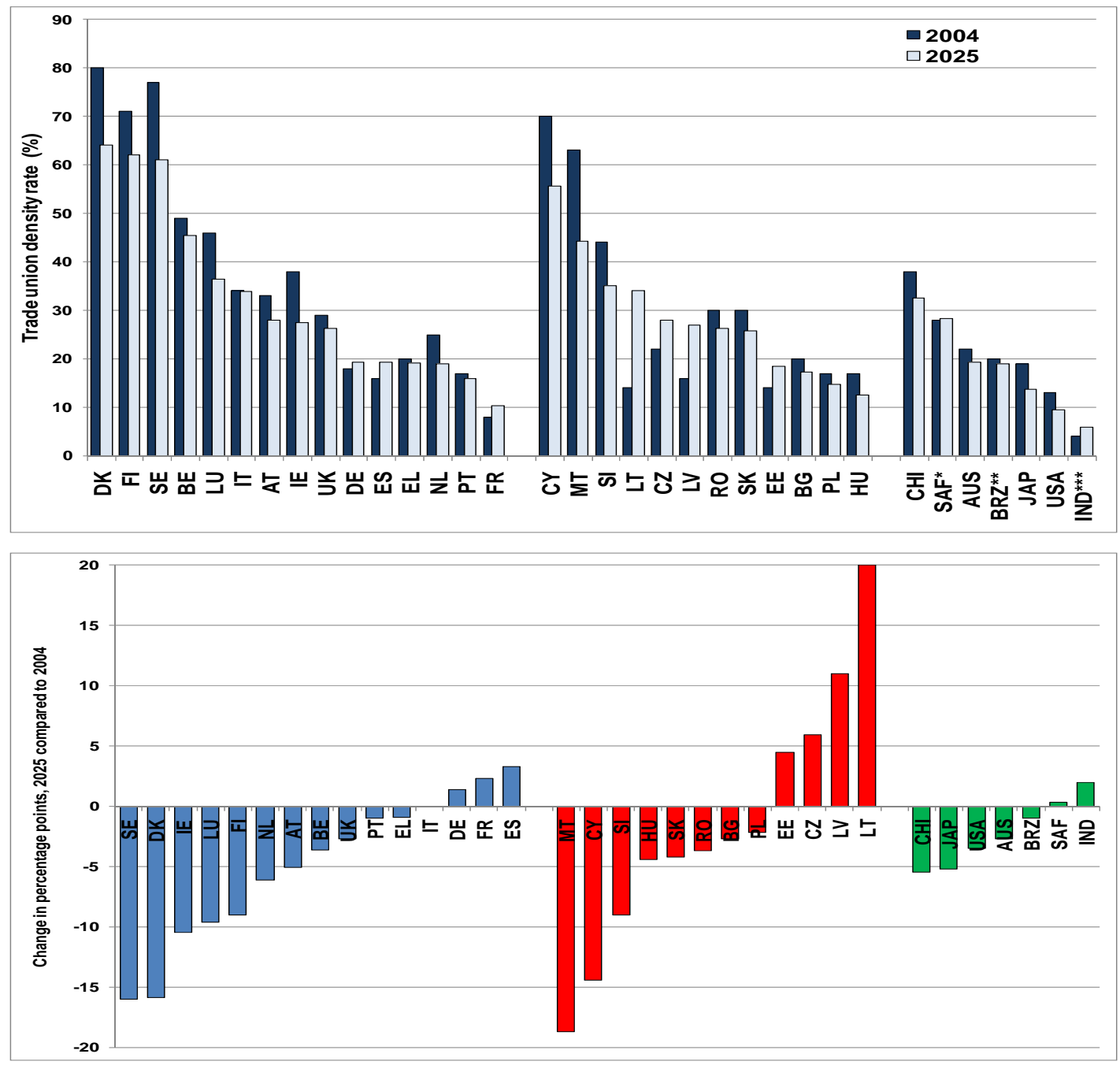

Figure 2. Trade union density rates in 2004 and foresight on trade union density rates in 2025 (percentage) (Lower figure: Change from 2004 to 2025). Question: "Please estimate, what will be the trade union density rate (i.e., share of employees belonging to trade union) in 2025 in your country (\%)". Notes. * According to South African expert Philip Hirschsohn, in 2001, trade union density rate corresponded to almost $43 \%$ of those employed in the formal sector of the economy, but only to $28 \%$ of the economically active population due to high levels of unemployment. ${ }^{* *}$ According to Brazilian expert Hélio Zylberstajn, the Brazilian unionisation rate in 2004 is overestimated for the following two reasons: First, Brazilian trade unions are entitled to a "union contribution" which equals the wage of one and which is compulsorily and controlled once a year; Secondly, older workers in rural areas need a statement from the trade union justifying that they are rural workers, in order to receive their pension benefit. ${ }^{* * *}$ For India 2004 figures concern only the formal sector. Various sources provide different estimates for trade union density rate in India, ranging from 2.6\% to 6\%. Sources: Van Gyes et al, 2007; Industrial relations foresight 2025 survey.

\section{Foresight on Employer Organisation Density Rates}

In 2004, the employers' density rates in the EU countries differed significantly, ranging from a $100 \%$ of density rate in Austria to 20\% in Poland (Philips \& Eamets, 2007; Van Gyes et al., 2007).

In 2025 the highest employer organisation density rates in the EU member states will be in Austria, 
Netherlands, and Luxembourg (over 80\%) and the lowest density rates (less than 30\%) will be in Poland and Slovakia (see Figure 3).
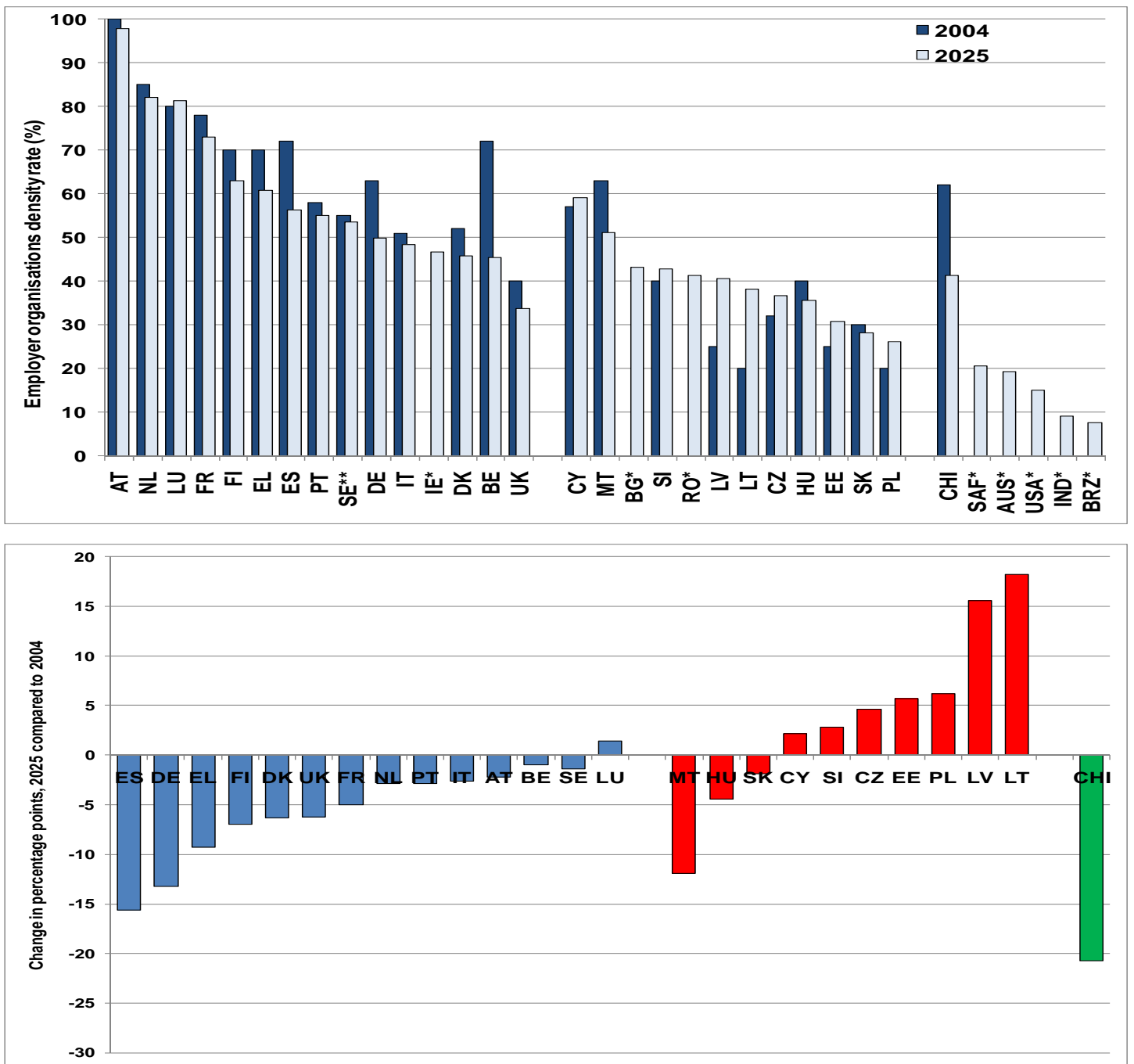

Figure 3. Employer organisation density rates in 2004 and foresight on employer organisation density rates in 2025 (percentage) (Lower figure: Change from 2004 to 2025). Question: Please estimate, what will be the employer organisations density rate (i.e., share of employees working for employers, who are members of an employer organisation) in 2025 in your country (\%). Notes. ${ }^{*}$ No reliable statistics about employer organisations density rate in 2004 exist for Ireland, Bulgaria, Romania, South Africa, Australia, U.S, India, and Brazil. In Japan, the concept of employer organisations density is missing; ${ }^{* *}$ According to Swedish respondents, the employer organisations density rate 55\% in 2004 in incorrect and is around 20 percentage points less than the correct figure. In December 2006 employer organisations density rate in the private sector was $76 \%$ and including employer organisations within the public sector the rate was 83\% at the end of 2006. Sources: Van Gyes et al., 2007; Industrial relations foresight 2025 survey.

Expert foresight shows that in global seven countries the employer organisation density rate will remain lower than in the EU member states in 2025. Trend comparison cannot be made because no comparable data exists for the Global seven countries: majority of these countries do not gather such statistics or no reliable estimates of employer organisations density exist, as is the case in Australia. The concept of employer organisations density is missing in Japan. 
- Majority of the EU 15 countries will see the modest decline in employer organisations density rates. Only in Spain and Germany, respondents expect deeper decline;

- In majority of EU 12 countries employer organisations' density rates will increase by 2025. Highest increase is expected in Lithuania and Latvia and biggest decline in Malta;

- In Global seven countries the employer organisations' density rates will be lower than $20 \%$ in 2025 but in China $41 \%$ compared today's unionisation of $62 \%$.

In the old EU 15 countries there is a clear tendency that employers' organisation density will decrease and in the new EU 12 countries increase. Exceptions are Malta and Cyprus where foresights show lowering tendency. In Global seven countries employer organisation rate will be very low.
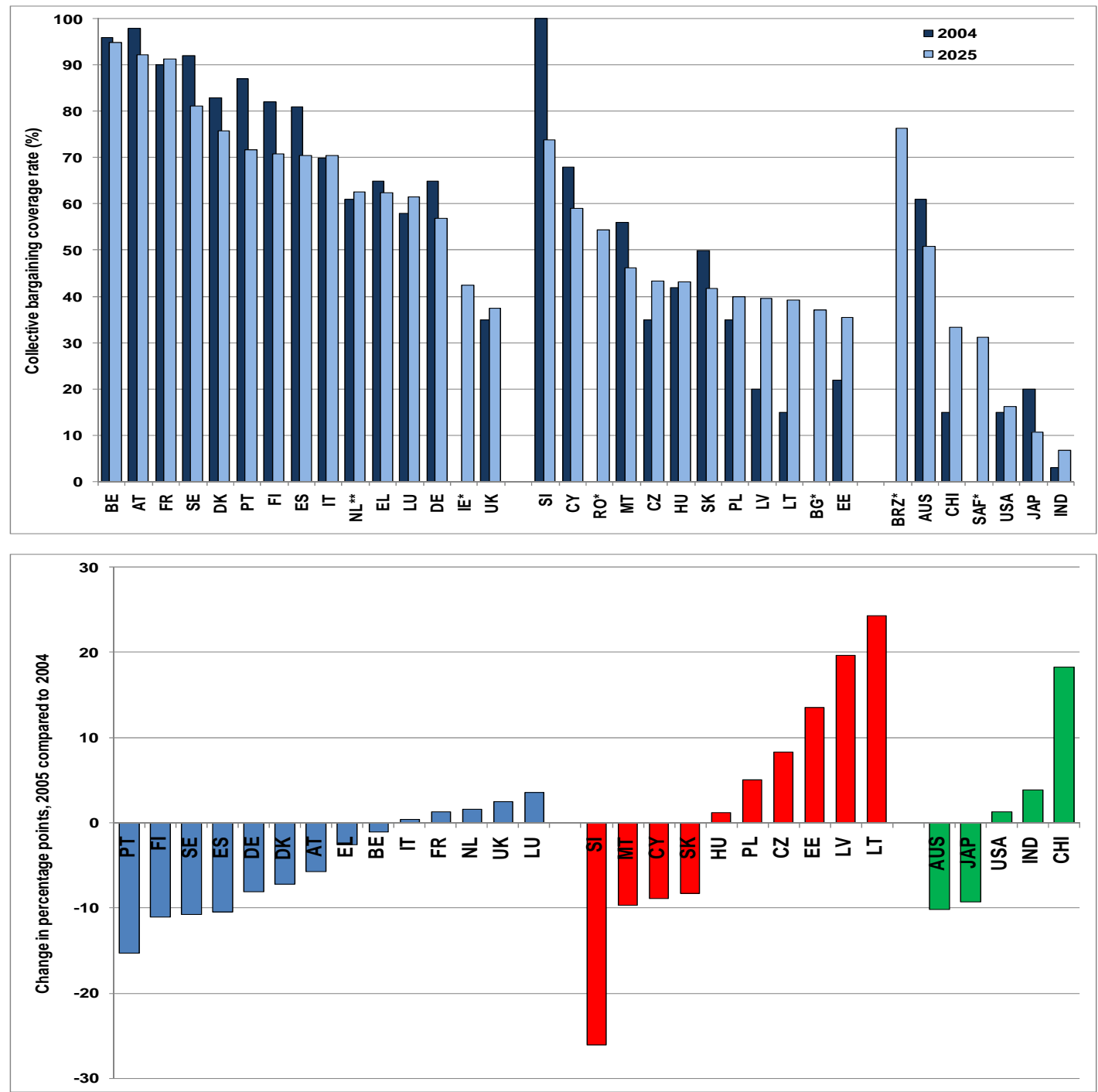

Figure 4. Collective bargaining coverage rates in 2004 and foresight on collective bargaining coverage rates in 2025 (percentage) (Lower figure: Changer from 2004 to 2025). Question: Please estimate, what will be the collective bargaining coverage rate (i.e., the share of employees covered with collective agreements) in 2025 in your country (\%). Notes. * There is no reliable information available about collective bargaining rate in 2004 for Ireland, Bulgaria, Romania, Brazil, and South Africa; ${ }^{* *}$ According to comments of two respondents from the Netherlands, the collective bargaining coverage rate is around $80-85 \%$ ever since World War II. Sources: Van Gyes et al., 2007; Industrial relations foresight 2025 survey. 


\section{Foresight on Collective Bargaining Coverage}

In 2004, collective bargaining coverage rate was around 75\% in the EU 15 and 30\%-40\% in the EU 12. In Global seven coverage rates vary but are in general much lower than the EU average (Van Gyes et al., 2007; Philips \& Eamets, 2007).

According to foresight 2025, the variability in collective bargaining coverage rates will remain also in future ranging from more than $90 \%$ in Belgium, Austria, and France to less than 15\% in India and Japan (see Figure 4).

Majority of respondents from the EU 15 countries expect some decline in coverage rates of collective agreements, while on average, some increase in coverage rates is expected in the EU 12 and the Global seven countries.

- In majority of the EU 15 countries the collective agreement coverage rate will decline by 2025. Luxembourg, the United Kingdom, the Netherlands, France, and Italy will see modest increase in the collective bargaining coverage rates;

- In the EU 12 countries collective agreement coverage rate is expected to decline in Slovenia, Malta, Cyprus, and Slovakia and highest increase in the Baltic States;

- Australia and Japan will see a decline in the collective agreement coverage rates, while in China, India, and the U.S. some increases will expected by 2025.

A short conclusion is that some convergences and unification in collective bargaining coverage rates is taking place in Europe but globally development does not seem very united.

\section{Foresight on Dominant Level of Collective Bargaining 2025}

Foresight 2025 show that there is some increase in sectoral level collective bargaining in the EU 12 countries and increasing importance of enterprise level bargaining among EU15 countries (see Figure 5).

- In 2004 national level collective bargaining took place in Finland, Ireland, and Slovenia but according to the expert foresight 2025 only in Ireland negotiations will take place in the national level. Finland and Slovenia are moving to sectoral level negotiations;

- In majority of the EU 15 countries the dominant level of collective bargaining in 2004 was sectoral level. The same will take place in 2025;

- In the UK company level agreement have be a common practice and it will continue in 2025. Also Greece will negotiate in the future on the workplace level instead of today's practice of sectoral level negotiations;

- In majority of the EU 12 countries the enterprise level collective bargaining will be dominant in the future. In 2004, sectoral level collective bargaining was dominant level in Cyprus and Slovakia, while the dominant level in 2025 will be enterprise level. Reverse tendencies are expected in Bulgaria, Estonia, Lithuania, and Slovenia, where the dominant level of bargaining in 2025 is expected to be sectoral level;

- Among Global seven countries sectoral level collective bargaining is dominant feature today in Brazil and South Africa and will also be so in 2025. The U.S. will have sectoral level collective agreement instead of enterprise agreements of today. Australia, China, India, and Japan will have enterprise agreements in 2025 as a dominant feature as they also have today. 


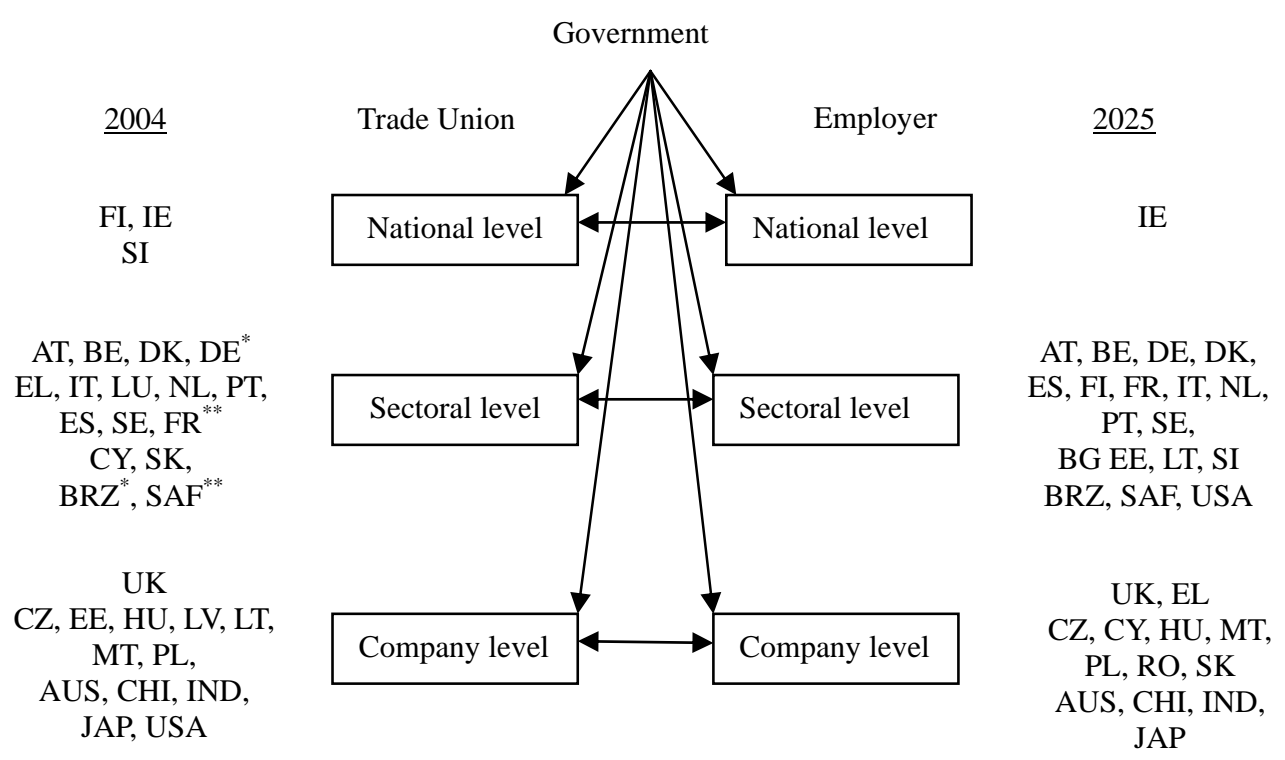

Figure 5. Collective bargaining levels in 2004 and foresight on dominant collective bargaining level in 2025. Question: What will be the dominant level of collective bargaining in your country in 2025. Please choose only one of the following: national level, sectoral/branch level, state/regional level, enterprise level, no collective agreements at all. Notes. In $2004{ }^{*}$ also regional level collective bargaining is important; ${ }^{* *}$ also company level collective bargaining is important. In Luxembourg equal share of respondents expect that the dominant level of collective bargaining in 2025 will be either sectoral level or enterprise level; in Latvia equal share of respondents expect that the dominant level of collective bargaining will be national, sectoral or enterprise level. Sources: Kauppinen, 2006; EIRO, Country profiles, 2006; Philips and Eamets, 2007; Industrial relations foresight 2025 survey.

\section{Conclusions}

Industrial relations foresight 2025 survey respondents had a joint view that liberalism in economic policy will increase as well as individualism in everybody's life. Working life flexibility will increase and more and more people are working as self-employed and in atypical employment relations. Job security is also weakening and inequality in incomes is widening by 2025 .

In the EU there are two contradictory trends: in majority of the EU 15 countries industrial relations are in weakening and strengthening is taking place in the EU 12 countries. Weakening means general trend towards lower unionisation for employees and lower organisational density for employers, moving towards workplace level negotiations and as a consequence less and less people are covered by collectively negotiated agreements. Strengthening in EU 12 countries means higher unionisation and better employer density as well as moving towards sectoral level collective bargaining. All in all an outcome of these contradictory trends is that industrial relations in European Union are in the process of convergence towards Europeanisation of industrial relations.

Globalisation trend in industrial relations is also observable from respondents' replies. Benchmarking the EU and the Global seven countries shows that China's industrial relations are in a pressure of liberalisation out from state and communist party control. Japanese spring negotiation offensive, shunto, is loosing its meaning at the same time when employee unionisation is weakening. In Australia and South Africa industrial relations are expected to remain like today. In India there are some weak signs of strengthening of industrial relations as well as in Brazil. Benchmarking these quite stabile Global seven trends against the general weakening of EU industrial relations shows that we can find some "weak signals" on globalisation of industrial relations. 


\section{Intermediate Evaluation 2012}

At the moment there are five years since the foresight 2025 survey was done. When making some intermediate observations, it is important to notice that ongoing economic downturn started to take effect in mid-2008 - half a year later than survey material was gathered. From the United States started industrial downturn affected strongly into all European Union Countries as well as globally. The recession led to a deep banking crisis especially Ireland and in Southern European countries and rapidly increasing unemployment globally.

As an intermediate conclusion based on the EIRO national reports it can be said that the economic downturn has weakened European social partners in working life. Especially trade unions' role has diminished with lowering membership numbers and weaker negotiation powers. Trade unions are on the defensive side with some industrial actions. Intersectoral agreements are rare and take many forms. The most common are sectoral collective agreements and it looks that company level wage-setting is taking more and more room. These trends are actual today but they are in line with the survey 2025 results. However, it is too early to make any further conclusions because before 2025 we will see some economic booming years as well as downturns and we have to remember that industrial relations development is also dependent on general world wide value trends.

\section{References}

Eurofound. (2007a). National reports on social dialogue capacity building in the national level in the EU10 and Bulgaria, Romania, Turkey and Croatia. Retrieved from http://www.eurofound.europa.eu

Eurofound. (2007b). National reports on social dialogue capacity building in the sectoral and company level in the EU10 and Bulgaria, Romania, Turkey and Croatia. Retrieved from http://www.eurofound.europa.eu

European Union. (2002). Thinking, debating and shaping the future: Foresight for Europe. Final report prepared by a High Level Group for the European Union.

Kauppinen, T. (2006). Industrial relations, future trends and challenges of globalisation. Proceedings from Eurofound foresight conference. Berlin.

Parisaki, M. (2007a). Social dialogue capacity building in the sectoral and company level in the EU10 and Bulgaria, Romania, Turkey and Croatia. Retrieved from http://www.eurofound.europa.eu

Parisaki, M. (2007b, 2008). Benchmarking working Europe 2008. European Trade Union Institute for Research, Education and Health and Safety (ETUI-REHS), Brussels, ETUI-REHS and ETUC.

Philips, K., \& Eamets, R. (2007). Impact of globalisation on industrial relations in the EU and other major economies. Retrieved from http://www.eurofound.europa.eu

Van Gyes, G., Vandenbrande, T., Lehndorf, S., \& Kohl, H. (2005). Industrial relations country profiles for each of the EU 25 Member States. Retrieved from http://www.eurofound.europa.eu

Van Gyes, G., Vandenbrande, T., Lehndorff, S., Schilling, G., Schief, S., \& Kohl, H. (2007). Industrial relations in EU Member States 2000-2004. Retrieved from http://www.eurofound.europa.eu 